\title{
Coming to Terms With Living Shorelines: A Scoping Review of Novel Restoration Strategies for Shoreline Protection
}

\author{
Carter S. Smith ${ }^{1 *}$, Morgan E. Rudd ${ }^{1}$, Rachel K. Gittman ${ }^{2}$, Emily C. Melvin ${ }^{1}$, \\ Virginia S. Patterson ${ }^{1}$, Julianna J. Renzi ${ }^{1}$, Emory H. Wellman ${ }^{2}$ and Brian R. Silliman ${ }^{1}$ \\ ' Duke University Marine Laboratory, Nicholas School of the Environment, Beaufort, NC, United States, ${ }^{2}$ Department of \\ Biology and Coastal Studies Institute, East Carolina University, Greenville, NC, United States
}

\section{OPEN ACCESS}

Edited by:

Wen-Cheng Wang,

National Taiwan Normal

University, Taiwan

Reviewed by:

Rochelle Diane Seitz,

William \& Mary's Virginia Institute of Marine Science, College of William \&

Mary, United States

Austin T. Humphries,

University of Rhode Island,

United States

${ }^{*}$ Correspondence:

Carter S. Smith

carter.smith@duke.edu

Specialty section: This article was submitted to Marine Conservation and Sustainability,

a section of the journal Frontiers in Marine Science

Received: 11 March 2020 Accepted: 18 May 2020

Published: 10 June 2020

Citation:

Smith CS, Rudd ME, Gittman RK, Melvin EC, Patterson VS, Renzi JJ, Wellman EH and Silliman BR (2020)

Coming to Terms With Living

Shorelines: A Scoping Review of Novel Restoration Strategies for Shoreline

Protection. Front. Mar. Sci. 7:434 doi: 10.3389/fmars.2020.00434
In an era of rapid coastal population expansion and habitat degradation, restoration is becoming an increasingly important strategy for combating coastal habitat loss and maintaining ecosystem services. In particular, techniques that use habitat restoration alone or restoration in combination with built infrastructure to provide coastal protective services are growing in popularity. These novel approaches, often called living shorelines, have the potential to expand the reach and applicability of coastal restoration projects. To understand how living shorelines research has expanded over time, we conducted a scoping review of English-language peer-reviewed articles. We included papers that self-identified as living shorelines research, as well as studies that used other related terminology, to investigate trends in publication rates, geography, site characteristics, and outcomes measured. Using a systematic search protocol, we compiled a database of 46 papers; the earliest study was published in 1981, and the earliest study to use the term living shoreline was published in 2008. Eighty-three percent of studies were conducted in North America, followed by $11 \%$ in Asia, and $7 \%$ in Europe, but the use of the term living shoreline was almost exclusively restricted to North America. Saltmarshes, oyster reefs, mangroves, and freshwater vegetation were used in living shoreline designs, but 91\% of studies also incorporated structural materials like oyster shell and rock. Most living shorelines research was conducted at sites that were $<5$ years old. The vast majority of studies exclusively reported on ecological outcomes (89\%), and of those, ecological processes were measured in $74 \%$ of studies. Processes related to coastal protection were measured most frequently (52\% of ecological studies), followed by biological interactions, water filtration, nutrient cycling, and carbon sequestration. Altogether, our data suggest that living shorelines research is on the rise, but there is a need for more long-term data, socio-economic research, further consensus on the terminology used to describe different types of projects, and research on the types of living shorelines that are most effective in different environmental contexts. Future long-term and interdisciplinary research will help to elucidate the full effects of living shorelines.

Keywords: natural infrastructure, nature-based solution, coastal protection, habitat degradation, ecosystem service, ecological engineering, hybrid infrastructure 


\section{INTRODUCTION}

Coastal habitats provide ecologically and economically important ecosystem services-they protect shorelines, cycle nutrients, support fisheries, promote tourism, and sequester carbon (Barbier et al., 2011; Mcleod et al., 2011; Scyphers et al., 2011; Silliman et al., 2019). These habitats and associated services, however, are under threat from a variety of human impacts including climate change (Hoegh-Guldberg and Bruno, 2010; He and Silliman, 2019), urbanization (Bertness et al., 2004), land reclamation for aquaculture and development (Lee et al., 2006), and overexploitation of key species (Coleman and Williams, 2002). In the two decades between 1980 and the turn of the century, 35\% of mangroves were lost worldwide and mangrove cover is projected to continue declining (Valiela et al., 2001). Similarly, human impacts destroyed $67 \%$ of wetlands in 12 major estuaries across Europe, Australia, and the United States (Lotze et al., 2006). Finally, in the most extreme ecosystem-specific case, $85 \%$ of historic oyster reefs have been lost and many remaining reefs are in poor condition (Beck et al., 2011). In response to these widespread declines, conservation practitioners are turning to restoration in an effort to slow and potentially reverse coastal ecosystem loss.

The number of scientific articles published annually on coastal restoration has increased dramatically in recent years (Zhang et al., 2018), and diverse restoration projects are being implemented worldwide (Bayraktarov et al., 2016). The original intent of restoration was to return an ecosystem to a close approximation of its original condition (NRC, 1992), but this may not be widely feasible going forward because of climate change, widespread human impacts, conflicting uses, and ecosystems that have been forced into alternate stable states (Hobbs and Norton, 1996). As such, the field of ecological engineering has emerged over recent decades with the goal of sustainably restoring habitats in a way that benefits both humans and the environment, especially in areas that are experiencing ongoing human pressure (Mitsch, 2012). In particular, there is rising interest in ecological engineering alternatives for traditional coastal protection infrastructure (Cheong et al., 2013; Sutton-Grier et al., 2015).

The proliferation of coastal defense structures is likely as coastal populations grow and hazards intensify (Scyphers et al., 2011; Hinkel et al., 2014); however, common coastal armoring strategies (e.g., seawalls, revetments, groins) can drive habitat loss (Titus, 1998), lower floral and faunal biodiversity (Gittman et al., 2016a), and depress socio-economic resilience by requiring frequent and expensive maintenance (Smith et al., 2017, 2018). Accordingly, ecosystem-friendly alternatives to traditional coastal defense structures are becoming more prevalent in areas where maintaining a natural shoreline is not possible. These techniques rely on some combination of natural or living materials and built infrastructure; they can meet a socioeconomic need, by providing enhanced shoreline protection, and they can also expand the reach of restoration projects into urbanized areas. The terminology used to refer to these projects is diverse and includes (but is not limited to): natural and naturebased infrastructure (Sutton-Grier et al., 2018), nature-based solutions (Nesshöver et al., 2017), hybrid infrastructure (SuttonGrier et al., 2015), ecosystem-based coastal defense (Temmerman et al., 2013), soft ecological engineering (Strain et al., 2019), and living shorelines. Non-standardized terminology can cause miscommunication and lead to flawed or reduced information sharing among scientists, practitioners, managers, and coastal residents (Bilkovic et al., 2017).

The term "living shoreline" is quickly becoming one of the primary terminologies used by practitioners, management agencies, and policy makers in the USA to refer to novel restoration projects for shoreline protection (e.g., Maryland's Living Shorelines Protection Act of 2008, the United States Army Corps of Engineers Nationwide Permit for Living Shorelines, and the Living Shorelines Act of 2019). The term living shoreline is not consistently defined, but generally refers to a suite of shoreline protection schemes that incorporate habitat restoration alone or in combination with some type of built infrastructure to provide coastal protective services to humans (NOAA, 2015). Living shoreline designs are often categorized along a green to gray spectrum, spanning from vegetative plantings for coastal protection on the green end to habitat restoration in conjunction with structural materials on the gray end (Figure 1). Living shorelines are touted for their potential to provide triple-bottom line returns (i.e., ecological, social, and economic benefits) by enhancing coastal habitat function (Currin et al., 2008; Davis et al., 2015; Gittman et al., 2016b) and increasing community resilience to storms (Manis et al., 2015; Smith et al., 2018), while requiring less maintenance and fewer repairs than traditional coastal armoring infrastructure (Smith et al., 2017, 2018). States within the USA have instituted local-level policies to encourage the installation of living shorelines, and on a national level, the US House of Representatives passed the Living Shorelines Act of 2019 to assist local and state governments and non-profits with living shoreline creation. ${ }^{1}$ High-level interest in living shorelines may indicate an increased appreciation for the services that coastal habitats provide, but there are still unknowns related to the design and functionality of living shorelines in different environments. To increase the likelihood that living shorelines are successful at protecting coastal property and infrastructure, as well as delivering other ecosystem services, we need to ensure that restoration practice is based on the most up-to-date science and that the services most desired by coastal residents are being measured. Unfortunately, restoration practice is often based on anecdotal information rather than the systematic review of existing evidence (Pullin et al., 2004). For example, in a survey of managers of one of the most highly-protected wetlands in England, Sutherland et al. (2004) found that $77 \%$ of management actions were based on personal experience and only $2 \%$ were based on primary scientific literature. This is problematic, as common practices and assumptions based on personal experience are not always supported (Pullin and Knight, 2001).

To ensure that limited research and restoration funds for living shorelines are optimally allocated, and to reduce duplication of research efforts as well as information gaps, we

\footnotetext{
${ }^{1}$ Living Shorelines Act of 2019 (2019). U.S. House of Representatives.
} 

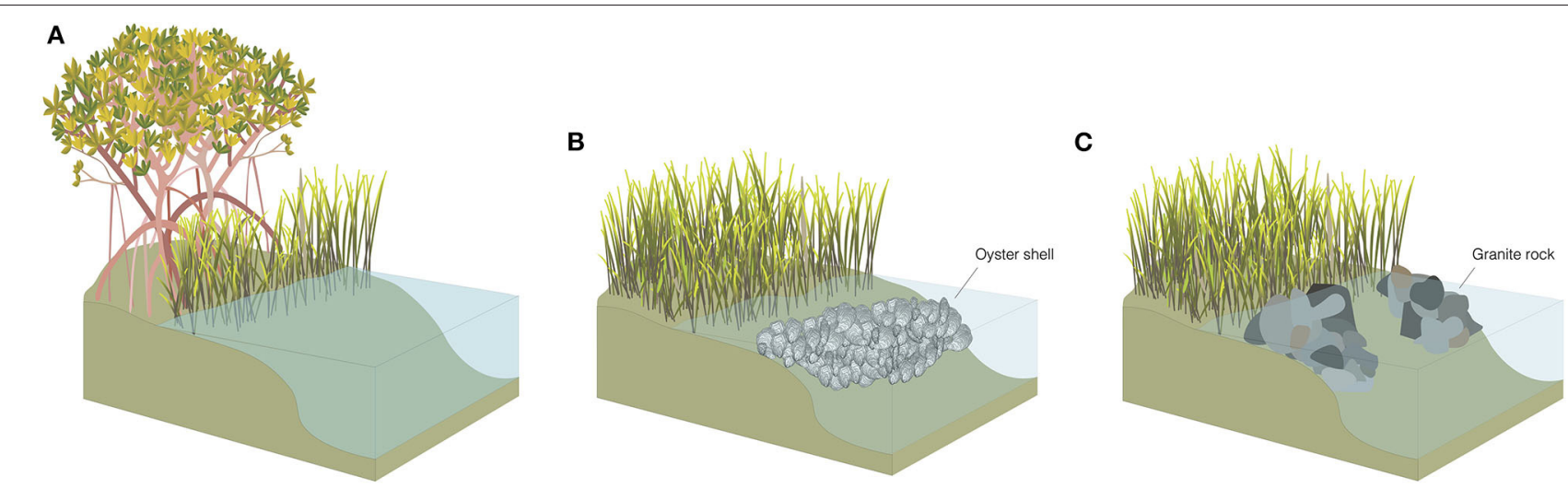

FIGURE 1 | Living shoreline spectrum illustrating three broad categories of living shorelines, including (A) vegetation plantings only, (B) restoration with soft materials (e.g., oyster shell, coir fiber), and (C) restoration with hard materials (e.g., granite rock, marl, concrete).

need a better understanding of which living shoreline practices and impacts are backed by scientific studies. The overarching goals of this scoping review were to: (1) characterize the Englishlanguage living shorelines literature; and, (2) identify research gaps and areas of concentrated research. In particular, we were interested in the following questions: (i) where has living shorelines research been conducted?; (ii) which types of living shorelines have been studied?; (iii) what is the disciplinary scope of the research that has been conducted and which outcomes have been measured?; and, (iv) what other terms are commonly used to refer to living shoreline projects?

\section{METHODS}

\section{Literature Search}

A challenge for reviewing living shorelines research is that the term itself is relatively new and is often used synonymously with other terminology. To fully characterize the field, we included papers that self-identified as living shorelines research (i.e., included the term in the text of the paper) as well as research that used alternate terminology, but that met our criteria for inclusion. We performed a preliminary search of the term "living shoreline" in Scopus and Web of Science to identify other terminology commonly used to refer to living shoreline projects. Synonyms identified during this search, along with terms compiled by the authors and terms suggested by external experts, were used to formulate the final search string.

We systematically searched Web of Science and Scopus in October 2019, using the search string: "living shoreline*" OR "bioengineer* hybrid technique*" OR "blue engineering" OR "blue infrastructure*" OR "build* with nature*" OR "created wetland*" OR "eco engineering" OR "ecosystem friendly engineering" OR "engineer* with nature" OR "green engineering" OR "green infrastructure*" OR "hybrid infrastructure*" OR "hybrid restoration technique*” OR "hybrid shoreline*" OR "hybrid stabilization*" OR "hybrid technique*” OR "natural infrastructure*” OR "nature based coastal management" OR "nature based feature*” OR "nature based infrastructure*” OR "nature based protection" OR "nature based saltmarsh restoration" OR "nature based shoreline*” OR "nature based solution*” OR "nature friendly bank protection*” OR "riprap mangrove habitat*" OR "soft engineering" OR "soft shoreline*" OR "soft stabilization*" OR "stabilized salt marsh*” OR "sill*”) AND ("shoreline*”). Additionally, we used a snowball approach and searched the bibliographies of the papers included from the database search and the bibliographies of several relevant literature reviews (Bilkovic et al., 2016; Gittman et al., 2016a; Dugan et al., 2018; Morris et al., 2018, 2019; Mitchell and Bilkovic, 2019). A full diagram of the search flow can be found in Figure 2 (Moher et al., 2009).

To be included in our database, all papers had to be English-language, peer-reviewed (no government reports, theses, etc.), and primary literature (no syntheses, conceptual papers, etc.). Additionally, each study had to include a physical living shoreline intervention (though it did not need to specifically be called a living shoreline) that: (1) included the restoration of a biogenic shoreline habitat; (2) mentioned that erosion control, sediment stabilization, or shoreline protection was a motivation for the project (or studied the same sites as another paper that mentioned that erosion control, sediment stabilization, or shoreline protection were project motivations); and, (3) maintained the land/water continuum (Bilkovic et al., 2017). Requiring a physical living shoreline intervention likely excluded some social and economic analyses from our database, but it was impossible to evaluate whether a project contained an appropriate living shoreline intervention when there were no project descriptions. We also excluded beach restoration projects from this synthesis, though they are sometimes considered living shorelines (Bilkovic et al., 2016, 2017), as living shorelines tend to be best suited for low to moderate- energy areas (United States Army Corps of Engineers, 2016), and beach-front projects are often subject to a different set of management and permitting regulations. Finally, the coastal protective services and ecosystem benefits of natural habitats as compared to hardened shorelines have been thoroughly reviewed elsewhere (Gittman et al., 2016a), and accordingly we focus on living shorelines where habitats were being actively restored. Going forward, all studies are referred to as living shorelines research, regardless of whether that term explicitly appeared in the text of the paper. 


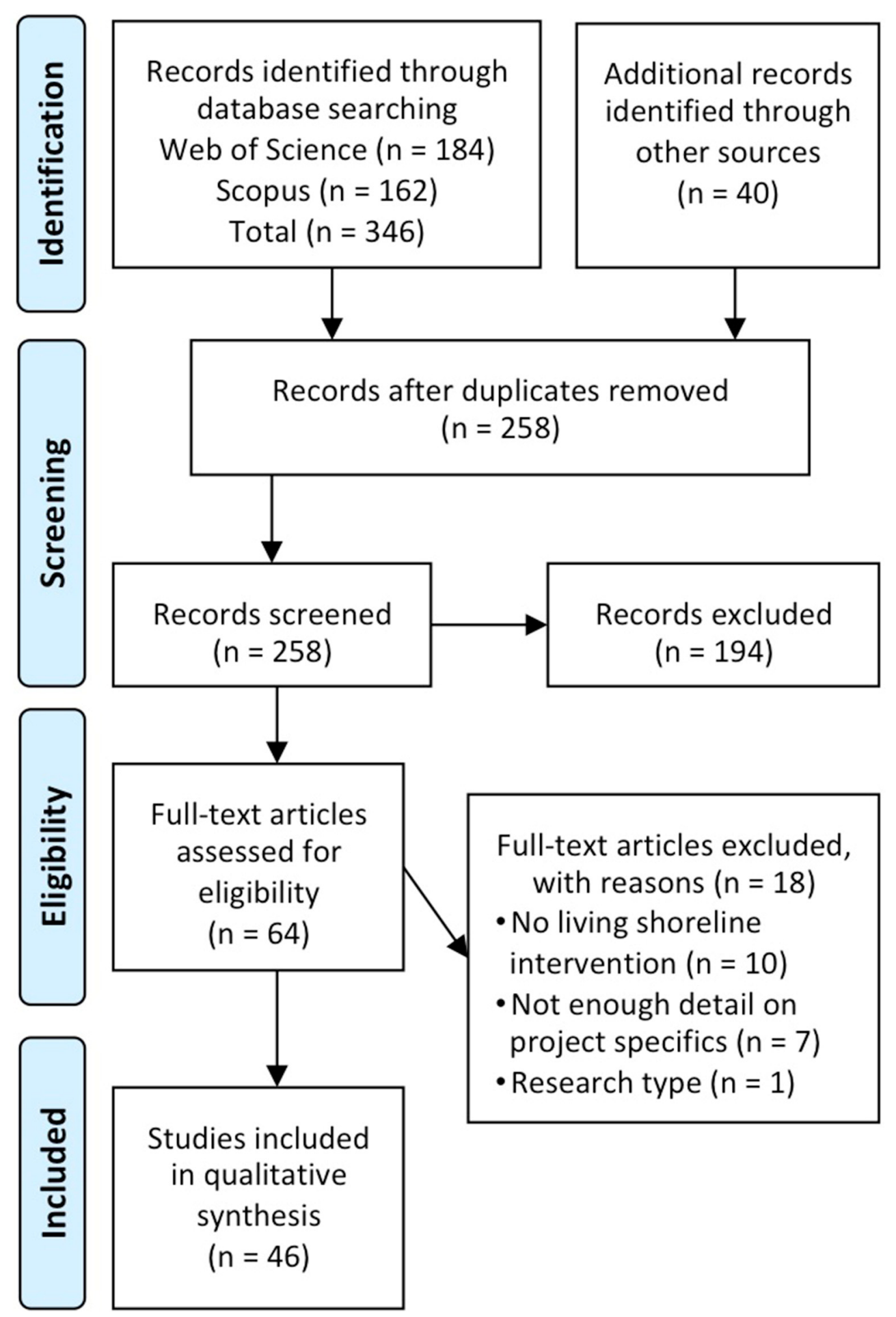

FIGURE 2 | PRISMA flow diagram for article selection.

\section{Data Extraction}

To ensure consistency, two independent reviewers conducted abstract screening and full-text data extraction. From each included study, we extracted bibliographic details (i.e., journal name, date of publication, and author affiliations), project descriptions (i.e., location, habitats restored, age, materials included in project design), metrics of study design (i.e., study type and comparators), and measured outcomes. Additionally, 
we noted whether or not the term "living shoreline" was included in the text of each paper and any relevant synonyms used to refer to the projects. When project age was reported, we recorded the age of each project at the time of the final sampling event; for papers looking at multiple projects, we report on the oldest living shoreline included in each study. For projects that had more than one type of non-living material incorporated into their designs (e.g., a rock breakwater in combination with coir logs) we categorized the project based on the grayest component of the design (e.g., rock). To characterize project outcomes, we first noted whether papers were reporting ecological or socio-economic outcomes. We further categorized ecological outcomes as focusing on foundation species structure (e.g., density, biomass, percent cover of the foundation species being restored), diversity and community abundance (i.e., community level metrics), and/or ecosystem processes (sensu Wortley et al., 2013). To evaluate the different terminology used to refer to living shoreline projects, we extracted synonyms from the title and abstract of each paper. We were interested in high-level terminology that could be applied to most living shoreline projects, thus we only included non-habitat specific synonyms (e.g., "restored oyster reef" and "stabilized saltmarsh" were not included). When an individual paper used the same word in multiple synonyms (e.g., "hybrid stabilization" and "hybrid shoreline protection"), the repeated word was only counted once in the frequency plot. The experimental unit for this synthesis is the individual paper rather than each living shoreline project, as multiple papers may have reported on the same project. All data are presented descriptively.

\section{RESULTS}

Our final database included 46 studies (Table 1). The earliest study was published in 1981 and the earliest study that included the term living shoreline was published in 2008 (i.e., Currin et al., 2008). The number of papers increased dramatically over time. Overall, $57 \%$ of studies included the term living shoreline (Figure 3A). Fifty-nine percent of studies had authors affiliated with only one sector (i.e., academic, governmental, non-governmental, or other/unknown), 35\% had authors that were affiliated with two sectors, and $6 \%$ had authors affiliated with three sectors. Academic affiliations were the most common ( $87 \%$ of papers), followed by governmental (43\%), nongovernmental (9\%), and other or unknown (9\%) (Figure 3B). Fifteen percent of all $1^{\text {st }}$ authors had cross-sector affiliations; $83 \%$ of $1^{\text {st }}$ authors were affiliated with academic institutions, followed by $24 \%$ affiliated with governmental organizations, $4 \%$ with non-governmental organizations, and $4 \%$ with other types of organizations. Sixty-one percent of studies used a field survey approach (e.g., observational studies), followed by field experiments (33\%), modeling (4\%), stakeholder interviews (4\%), and lab experiments (2\%) (Figure 3C); two studies used multiple approaches. Fifteen percent of studies had no comparator and $35 \%$ of studies had multiple comparators. Eighty-three percent of studies included a reference (natural or degraded) shoreline as a comparator, $20 \%$ compared to a hardened shoreline, $13 \%$ compared among different types of living shorelines, and $9 \%$ used another type of comparator (such as before-after or spacefor-time design) (Figure 3D). The studies were published in 26 different journals, with Ecological Engineering $(n=7)$ and Estuaries and Coasts $(n=5)$ being the most frequent (Table 1). Thirty percent of all studies were open access.

Studies were heavily concentrated in North America $(n=$ 38 ), followed by Asia $(n=5)$, and Europe $(n=3)$, with no studies included from other continents. The term living shoreline was used in the majority of North American studies (66\%), only used in one European study, and not used in any studies in Asia (Figure 4A). Within the continental United States, we found examples of living shorelines research in all Gulf States, most Atlantic coast states, and only one Pacific coast state, California. North Carolina had the highest number of studies $(n=14)$, followed by Florida $(n=7)$, Louisiana $(n=6)$, Maryland $(n=$ $5)$, Virginia $(n=5)$, and Alabama $(n=4)$ (Figure 4B).

Forty-five of the 46 articles in our database investigated living shorelines that were built in the field and one study built living shorelines in a laboratory setting (Manis et al., 2015). Of the 45 field studies, 27\% reported on a single living shoreline site and $78 \%$ included five or fewer living shoreline sites. Of the field studies that provided information about the age of any of the structures sampled $(n=41), 56 \%$ of the oldest structures sampled were younger than 5 years old and $76 \%$ were younger than 10 years old (Figure 5A). Four studies included sites that were more than 25 years old, and the oldest project was 52 years old (i.e., Knutson et al., 1981). Four of the 46 studies included living shorelines where different habitats were being restored at different sites. Thirty-five percent of papers included a site where saltmarsh was the only habitat restored, vs. $30 \%$ for oysters, $11 \%$ for mangroves, and $4 \%$ for freshwater vegetation. Twenty-two percent of articles included sites where saltmarsh and oysters were restored together vs. $0 \%$ for saltmarsh and mangroves, $2 \%$ for oysters and mangroves, and $4 \%$ for all three habitats (Figure 5B). Only 13\% of studies included living shoreline sites/designs where only vegetation was planted, whereas $91 \%$ of studies included sites that used soft or hard structural materials in addition to habitat restoration. Nine of the 46 studies investigated more than one living shoreline design (e.g., one site had a rock sill and another site had an oyster sill). Forty-eight percent of studies investigated sites that used shell, including loose shell, bagged shell, shell mats, and shell in gabion boxes. Only $4 \%$ of studies used coir logs as the only structural component. Nine percent of studies looked at sites with wooden breakwaters, $13 \%$ with concrete structures (e.g., oyster castles), and 33\% investigated sites with rock materials (Figure 5C).

Most studies in our database reported on purely ecological outcomes (89\%), with few studies reporting on socio-economic outcomes (Figure 6A). Within the ecological studies, foundation species structure was often measured (61\% of studies) but rarely as the only metric (5\%). Diversity and community abundance metrics were also often measured (49\% of studies), but rarely on their own (12\%). Of the 21 studies that measured diversity and community assemblage metrics, $24 \%$ only measured floral diversity, $62 \%$ only measured faunal diversity, and $14 \%$ measured both. Twelve of the 16 faunal studies measured diversity and 
TABLE 1 | Bibliographic information for included studies with location of study, habitats restored, and synonyms used to describe projects.

\begin{tabular}{|c|c|c|c|c|c|c|}
\hline No. & References & Journal & Country & Habitat type(s) & Synonyms & LS? \\
\hline 1 & Chowdhury et al. (2019) & Scientific Reports & Bangladesh & Oyster reef & Nature-based solution & \\
\hline 2 & Kibler et al. (2019) & Sustainability & USA & $\begin{array}{l}\text { Saltmarsh; Oyster reef; } \\
\text { Mangrove }\end{array}$ & & $\checkmark$ \\
\hline 3 & Wiberg et al. (2019) & Estuaries and Coasts & USA & Oyster reef & & \\
\hline 4 & Davenport et al. (2018) & Estuaries and Coasts & USA & Saltmarsh & & $\checkmark$ \\
\hline 7 & Onorevole et al. (2018) & Ecological Engineering & USA & Saltmarsh; Oyster reef & Nature-based solution & $\checkmark$ \\
\hline 8 & Palinkas et al. (2018) & Estuaries and Coasts & USA & Saltmarsh & & $\checkmark$ \\
\hline 9 & Polk and Eulie (2018) & Estuaries and Coasts & USA & Saltmarsh; Oyster reef & & $\checkmark$ \\
\hline 10 & Smith et al. (2018) & Ecological Applications & USA & Saltmarsh, Oyster reef & $\begin{array}{l}\text { Nature-based solution; rock } \\
\text { sill }\end{array}$ & $\checkmark$ \\
\hline 13 & Gittman et al. (2016b) & Ecological Applications & USA & Saltmarsh; Oyster reef & & $\checkmark$ \\
\hline 14 & Sharma et al. (2016) & Ecological Engineering & USA & Saltmarsh; Oyster reef & $\begin{array}{l}\text { Hybrid shoreline } \\
\text { stabilization; bioengineering } \\
\text { hybrid technique; hybrid } \\
\text { restoration technique }\end{array}$ & $\checkmark$ \\
\hline 15 & Walles et al. (2016) & Journal of Sea Research & Netherlands & Oyster reef & & \\
\hline 16 & Casas et al. (2015) & $\begin{array}{l}\text { Marine Ecology Progress } \\
\text { Series }\end{array}$ & USA & Oyster reef & & \\
\hline 17 & Davis et al. (2015) & PLOS ONE & USA & Saltmarsh; Oyster reef & $\begin{array}{l}\text { Natural infrastructure; hybrid } \\
\text { infrastructure }\end{array}$ & $\checkmark$ \\
\hline 18 & De Roo and Troch (2015) & $\begin{array}{l}\text { River Research and } \\
\text { Applications }\end{array}$ & Belgium & Freshwater vegetation & $\begin{array}{l}\text { Nature-friendly bank } \\
\text { protection }\end{array}$ & $\checkmark$ \\
\hline 23 & Milbrandt et al. (2015) & Ecological Engineering & USA & Oyster reef; Mangrove & $\begin{array}{l}\text { Multiple habitat restoration } \\
\text { strategy }\end{array}$ & \\
\hline 24 & Peters et al. (2015) & Bulletin of Marine Science & USA & Mangrove & & $\checkmark$ \\
\hline 25 & Scyphers et al. (2015b) & Environmental Management & USA & Oyster reef & Submerged breakwater & $\checkmark$ \\
\hline 26 & Van Cuong et al. (2015) & Ecological Engineering & Vietnam & Mangrove & Soft coastal engineering & \\
\hline 27 & Gittman et al. (2014) & $\begin{array}{l}\text { Ocean and Coastal } \\
\text { Management }\end{array}$ & USA & Saltmarsh & $\begin{array}{l}\text { Alternative shoreline } \\
\text { protection approach }\end{array}$ & \\
\hline 28 & La Peyre et al. (2014) & Ecological Engineering & USA & Oyster reef & & \\
\hline 29 & Lawless and Seitz (2014) & $\begin{array}{l}\text { Journal of Experimental } \\
\text { Marine Biology and Ecology }\end{array}$ & USA & Oyster reef & & $\checkmark$ \\
\hline 30 & Motamedi et al. (2014) & The Scientific World Journal & Malaysia & Mangrove & $\begin{array}{l}\text { Ecofriendly coastal } \\
\text { protection scheme }\end{array}$ & \\
\hline 31 & Bilkovic and Mitchell (2013) & Ecological Engineering & USA & Saltmarsh & Hybrid stabilization & $\checkmark$ \\
\hline 32 & De Roo and Troch (2013) & $\begin{array}{l}\text { Journal of Waterway, Port, } \\
\text { Coastal, and Ocean } \\
\text { Engineering }\end{array}$ & Belgium & Freshwater vegetation & $\begin{array}{l}\text { Environmentally friendly } \\
\text { bank protection }\end{array}$ & \\
\hline 33 & Moody et al. (2013) & $\begin{array}{l}\text { Marine Ecology Progress } \\
\text { Series }\end{array}$ & USA & Oyster reef & & $\checkmark$ \\
\hline
\end{tabular}


TABLE 1 | Continued

\begin{tabular}{|c|c|c|c|c|c|c|}
\hline No. & References & Journal & Country & Habitat type(s) & Synonyms & LS? \\
\hline 35 & Naohiro et al. (2012) & $\begin{array}{l}\text { International Journal of } \\
\text { Ecology }\end{array}$ & Thailand & Mangrove & & \\
\hline 36 & Kamali and Hashim (2011) & Ecological Engineering & Malaysia & Mangrove & & \\
\hline 37 & O'Connor et al. (2011) & $\begin{array}{l}\text { Wetlands Ecology and } \\
\text { Management }\end{array}$ & USA & Saltmarsh & Sill & $\checkmark$ \\
\hline 39 & Stricklin et al. (2010) & $\begin{array}{l}\text { Gulf and Caribbean } \\
\text { Research }\end{array}$ & USA & Oyster reef & & \\
\hline 40 & Currin et al. (2008) & $\begin{array}{l}\text { Wetlands Ecology and } \\
\text { Management }\end{array}$ & USA & Saltmarsh & & $\checkmark$ \\
\hline 41 & Piazza et al. (2005) & Restoration Ecology & USA & Oyster reef & $\begin{array}{l}\text { Sustainable shoreline } \\
\text { protection strategy }\end{array}$ & \\
\hline 45 & Benner et al. (1982) & Wetlands & USA & Saltmarsh & Vegetative erosion control & \\
\hline 46 & Knutson et al. (1981) & Wetlands & USA & Saltmarsh & Vegetative stabilization & \\
\hline
\end{tabular}

LS, indicates whether the term living shoreline was included in the full-text of the paper.
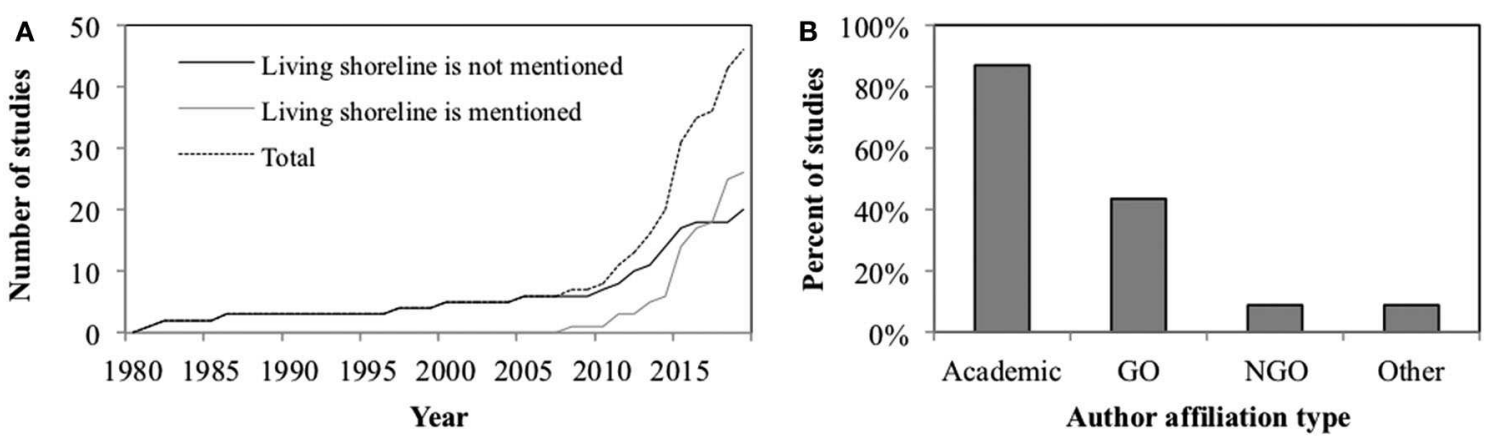

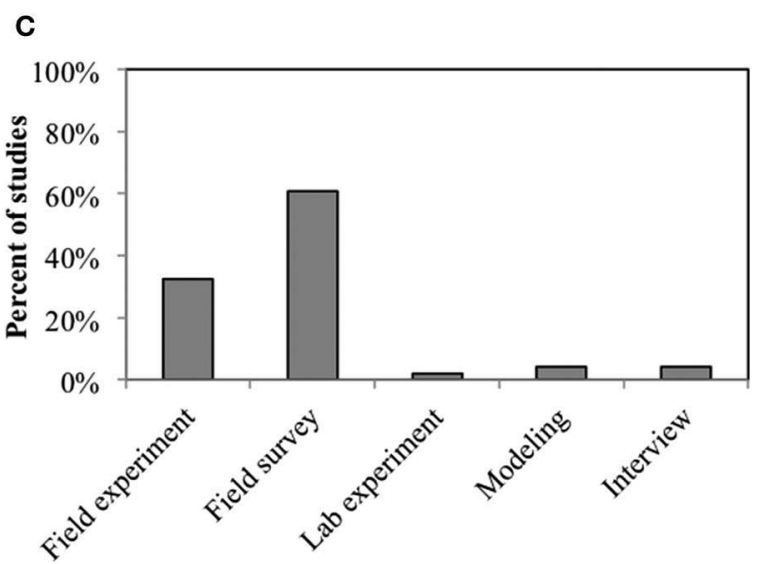

Study type

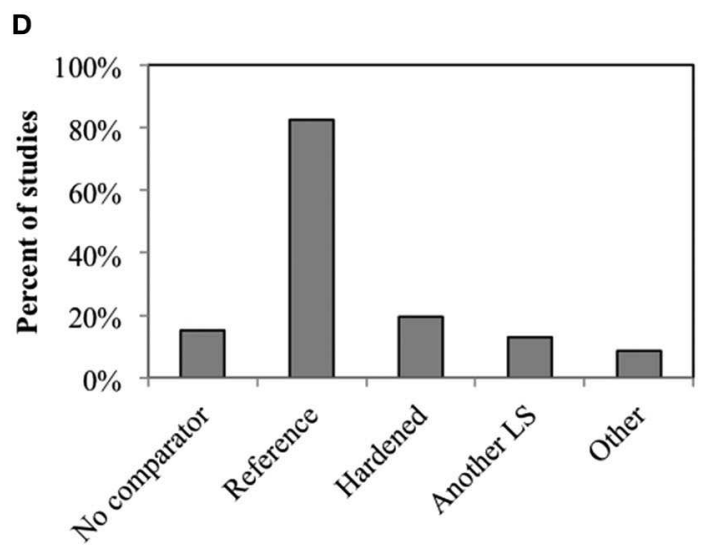

Comparator type

FIGURE 3 | Bibliographic information from studies, including (A) number of studies published over time, (B) author affiliations, (C) study type, and (D) comparator types. The bars in figures (B-D) do not add up to $100 \%$ as some studies had multiple author affiliations, study types, and comparators.

abundance within invertebrate and vertebrate communities, and the remaining four studies only measured within the invertebrate community. Ecological processes were the most common outcomes measured, with $74 \%$ of studies reporting on an ecosystem process (Figure 6B). More than half of all ecological studies (52\%) measured a process related to the 

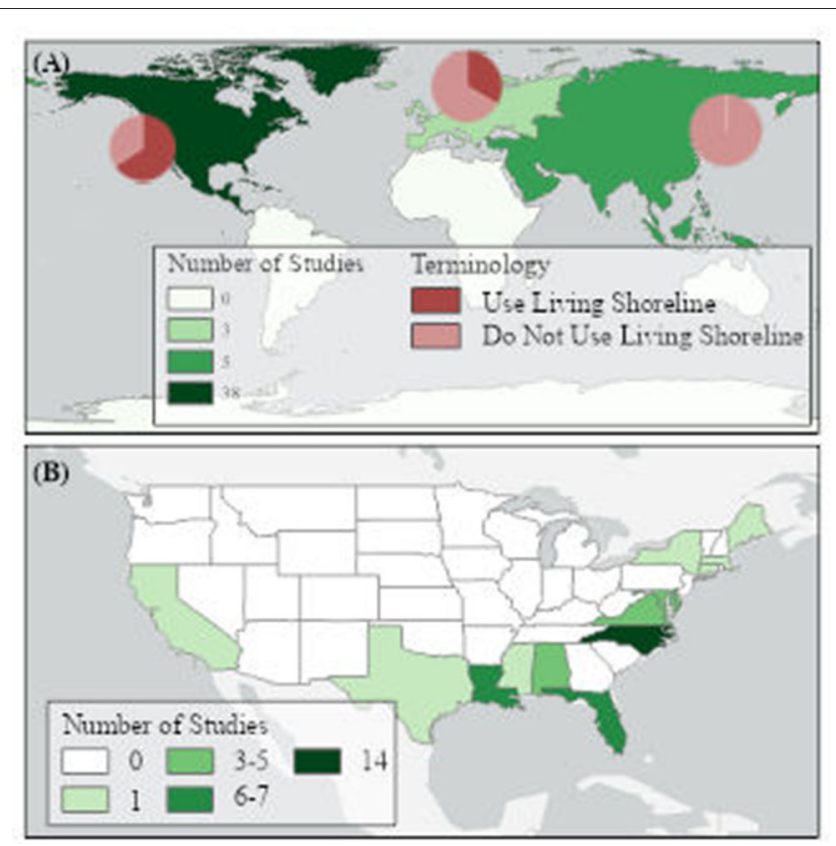

FIGURE 4 | Map of study distributions (A) globally and (B) in the continental United States. The global distribution indicates the number of studies from each continent and the proportion of studies within each continent that included the term living shoreline. Studies that included sites from multiple states count toward the total of each state.

coastal protection services of living shorelines (i.e., sediment stabilization, wave attenuation). Other measured ecosystem processes were biological interactions $(n=9)$, water filtration $(n=3)$, nutrient cycling $(n=1)$, and carbon storage $(n=1)$ (Supplementary Material).

The terminology used to refer to living shoreline projects was extremely diverse (Table 1). The most common words used in living shoreline synonyms were protection, nature, sill, based, and shoreline (Figure 7).

\section{DISCUSSION}

The number of living shorelines papers increased substantially over time, as did the proportion of studies specifically using the term living shoreline. This supports the idea that living shorelines are gaining momentum as a practice and research topic. Further, the term living shoreline has become a primary term used by the research community to refer to restoration projects that have a principal goal of providing coastal protective services. Interest in living shorelines has similarly increased within the practitioner and policy realm in the United States. For example, Restore America's Estuaries, a conservation nonprofit, maintains a living shorelines community of practice, through which practitioners and managers can network, access training modules, and view relevant webinars on the most upto-date research. Since its creation in 2016, this community of practice has grown 4-fold, with training modules and the companion website experiencing steady and constant traffic
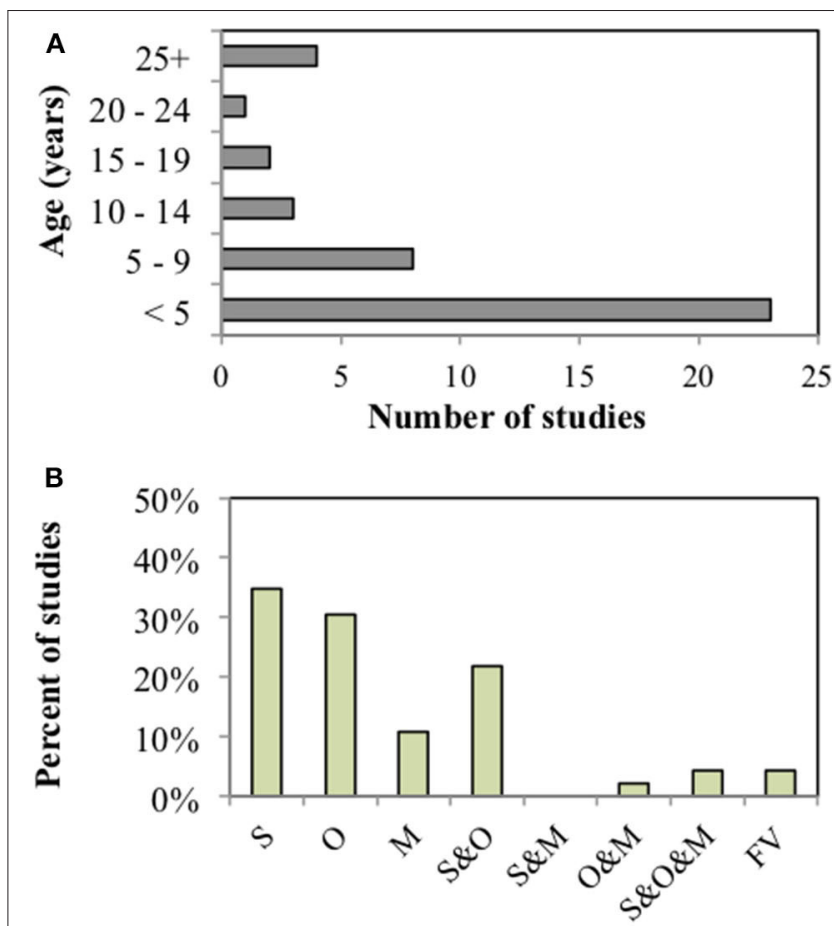

Habitats restored

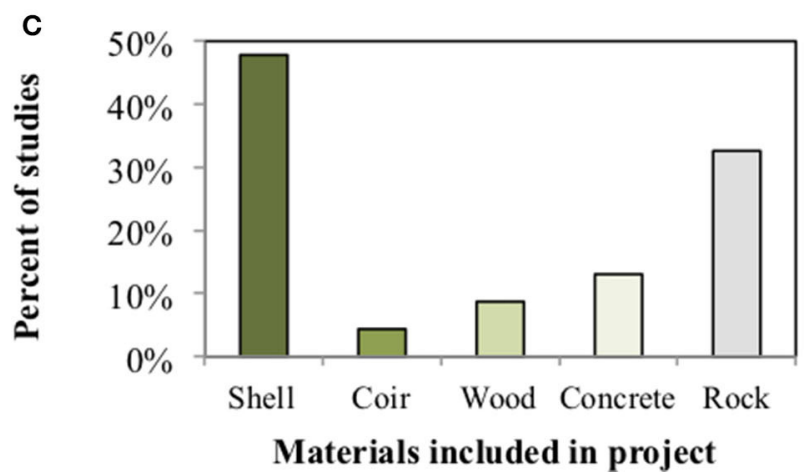

FIGURE 5 | Living shoreline project characteristics, including (A) maximum age of living shoreline projects when they were sampled, (B) habitat types restored within a single living shoreline site, and $\mathbf{( C )}$ materials used within a single living shoreline site. When there were multiple living shorelines in a single study, we report on the oldest living shoreline at the time of the last data collection. For $(\mathbf{B}, \mathbf{C})$, the bars do not add up to $100 \%$ as some articles investigated multiple types of living shorelines. In (B), S, saltmarsh; O, oyster; $\mathrm{M}$, mangroves; FV, freshwater vegetation; \& indicates that the habitats were restored together within a single site.

(personal communication $\mathrm{H}$. Stevens). Moreover, the recent passage of the Living Shorelines Act of 2019 within the US House of Representatives as well as a 2017 Nationwide Permit for the construction of living shorelines (United States Army Corps of Engineers, 2016), illustrate high-level interest in the promotion and construction of living shorelines. Nevertheless, for living shorelines to scale to a meaningful level, enthusiasm needs to be met by interdisciplinary evaluations of efficacy in different contexts. 


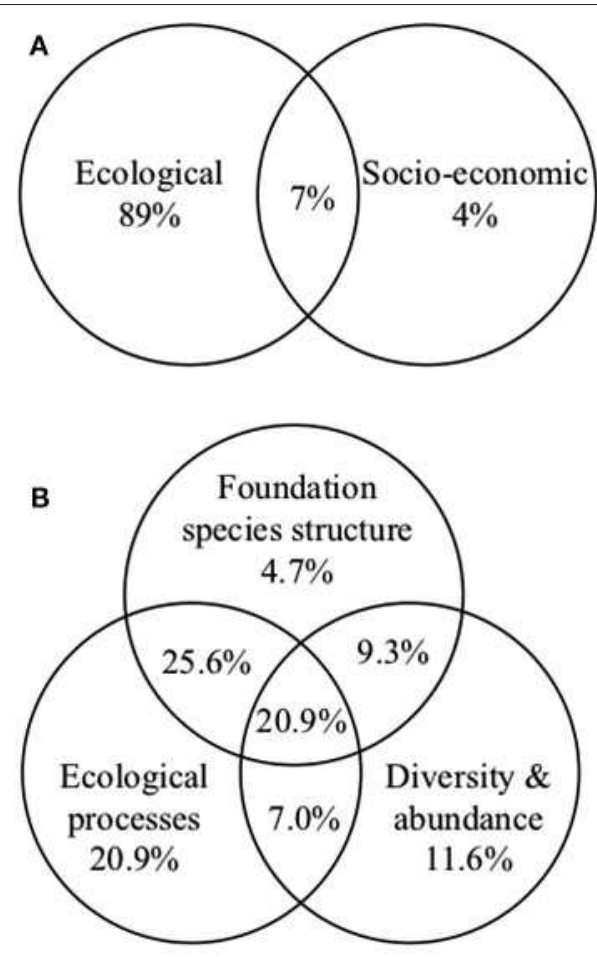

FIGURE 6 | Venn diagrams showing (A) the percentage of papers that reported ecological and socio-economic outcomes, and $(\mathbf{B})$ the percentage of ecological papers that reported outcomes related to foundation species structure, diversity and community assemblage, and/or ecosystem processes and functions.

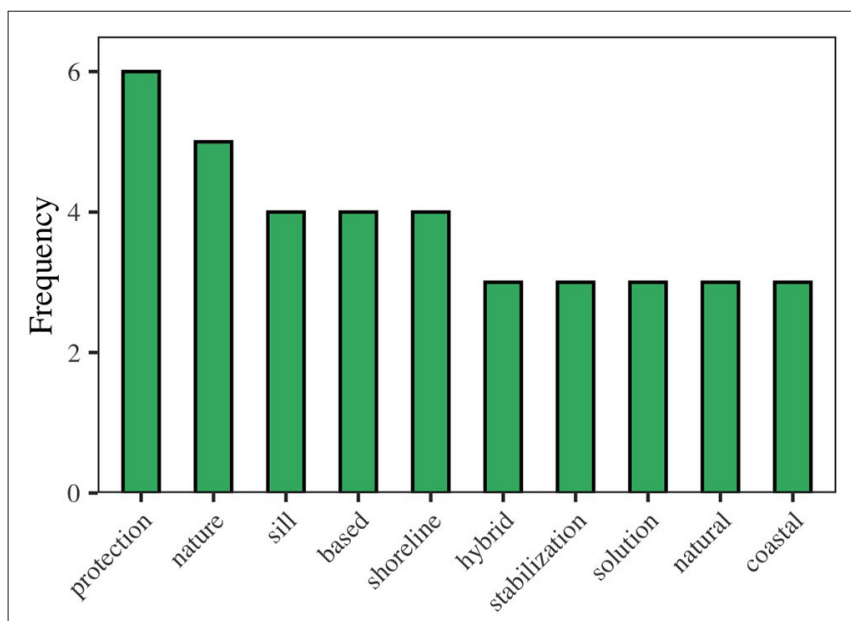

Word

FIGURE 7 | Bar graph showing the 10 most common words used in synonyms to describe living shoreline projects (all other words were used fewer than three times). Frequency also corresponds to the number of papers that used each word in at least one synonym.

Our results show that the vast majority of living shoreline studies had an ecological focus, with very few papers reporting socio-economic outcomes. These results are congruent with similar studies looking at habitat restoration in terrestrial
(Wortley et al., 2013) and marine biomes (Bayraktarov et al., 2019). Historically, restoration was aimed at replacing habitat that had been lost in order to restore ecological structure and function (NRC, 1992). These relatively narrow objectives and outcomes could be stated and measured by ecologists; now, however, there is increasing investment in restoration with broadened objectives that include maximizing the delivery of ecosystem services. As the breadth of desired restoration outcomes has expanded well beyond what can be measured by ecologists alone, so too must our assessments of these projects expand to include social and economic metrics (Eden and Tunstall, 2006; Martin, 2017). Living shorelines are fairly unusual because they have a high potential for private investment, as they provide an alternative to hardened shorelines that homeowners and municipalities are already accustomed to paying for (SuttonGrier et al., 2018). As such, a deeper understanding of why and in which types of communities living shorelines are being built could help to elucidate the factors that influence their social acceptability and implementation.

Nearly three quarters of the ecological studies in our database measured a process, rather than exclusively reporting on foundation species structure or diversity. In contrast, similar reviews of terrestrial restoration projects reported that ecosystem processes were measured less frequently than diversity metrics (Ruiz-Jaen and Aide, 2005; Wortley et al., 2013); the authors attributed these findings to the time and cost required to take multiple measurements over time rather than a onetime measurement of diversity or ecosystem structure. Unlike traditional restoration projects, living shorelines are designed and promoted as restoration techniques that provide explicit services to humans, namely coastal protection. This reflects a growing trend involving a shift away from the restoration of an ecosystem and toward the restoration of ecosystem services (Palmer et al., 2014). To measure an ecosystem service, it is necessary to measure whether the underlying process has been restored, which may explain why the studies in our database focused heavily on processes. Moreover, waterfront property owners in the United States prioritize effectiveness over all other attributes when choosing how to stabilize their shorelines (Scyphers et al., 2015a; Smith et al., 2017); appropriately, $>50 \%$ of all ecological studies in our database investigated a process related to the coastal protective services of living shorelines.

Living shoreline studies were heavily concentrated in the United States, with no studies from the Southern Hemisphere. At a global level, many of the most at-risk geographic regions have seen little research regarding living shorelines. For example, Asia is home to eight of the top ten countries with the largest populations in low-elevation coastal zones (McGranahan et al., 2007), yet only five of the living shoreline studies in our database took place in Asia. This finding may be due in part to: (1) an English-language publication bias; (2) fewer research institutions and lower funding in other countries; or, (3) different terminology than what was included in our search terms. Regardless, more studies from diverse locations could expand our understanding of which techniques and habitats can successfully be incorporated into coastal defense plans at a global scale. Within the continental United States, the largest concentration 
of research was in North Carolina. It can take time for new technology to gain momentum and familiarity among users, practitioners, and managers; thus, it is probably not coincidental that the earliest study in our database and the earliest study to use the term living shoreline were both conducted in North Carolina. Moreover, North Carolina was one of the earliest states in the country to issue a general permit for living shorelines (i.e., the General Permit for the Construction of Marsh Sills in 2005), which streamlined the process for constructing projects. As information about living shorelines continues to disseminate and management and policy avenues improve, we are likely to see an increase in research on a global scale. Nevertheless, the amount of primary research may not correlate with the prevalence of actual living shoreline projects. For example, while North Carolina has been a leader in peer-reviewed living shorelines research, according to our database, it is likely that there are fewer living shorelines projects in North Carolina vs. other areas (RAE's Living Shorelines Academy). Furthermore, North Carolina has certainly lagged behind on understanding and acknowledging the negative ecological effects of shoreline hardening relative to other areas, such as the Chesapeake Bay (see Seitz et al., 2006; Bilkovic and Roggero, 2008; Patrick et al., 2016 for a few examples), which has policies specifically identifying living shorelines as a preferable alternative to hardened shorelines (i.e., the Living Shorelines Protection Act of 2008). Further research into the distribution and characteristics of living shoreline projects themselves would be useful for characterizing the socioecological factors that influence their construction.

Currently, in the United States, the relative difficulty of completing the permitting necessary for installation of a living shoreline, as opposed to conventional shoreline protection structures (e.g., bulkheads), incentivizes construction of the latter. This differential burden stems partly from a desire by permitting agencies, and therefore property owners, to avoid projects that might encroach into public waters (National Research Council, 2007) or that have unknown or unproven effects. Research has been conducted on the ecological effects of shoreline hardening more broadly (Gittman et al., 2016a), but studies focused on the alternatives when maintaining a natural shoreline is not possible have lagged behind. Thus, a hurdle for the adoption of living shorelines as opposed to artificial protection is evaluation of the relative efficacy of both (Morris et al., 2018). While coastal protective services in general were well studied, only $20 \%$ of the studies in our database directly compared living shorelines to hardened shorelines. If living shorelines are to become a feasible alternative to hardened shorelines, we need research not only demonstrating that they actually work at stabilizing sediments, attenuating waves, and protecting property, but also demonstrating that they are as effective or more effective than the status quo (i.e., traditional engineering approaches). Furthermore, research on the relative costs of different living shoreline interventions is extremely limited (Gittman and Scyphers, 2017), though there is promising data from the wider field of nature-based infrastructure (Narayan et al., 2016). One significant advantage that living shorelines have over hardened shorelines is the potential to self-repair and adapt over time without continued human intervention. While this potential is promising, the majority of the projects in our database were young ( $<5$ years old) at the time of sampling and only provided a short-term snapshot of performance. Many ecosystem services require time to fully develop after restoration (La Peyre et al., 2014; Manis et al., 2015; Gittman et al., 2016b) and therefore longterm monitoring data will be critical to fully evaluate the functionality of living shorelines, particularly in the context of rising sea levels.

Given sustained interest in living shorelines among researchers, practitioners, and policy makers, the need for common terminology is particularly pressing. The terminology used to refer to living shorelines in this study was extremely diverse; even the same authors used different terms to refer to the same projects (see De Roo and Troch, 2013, 2015; Gittman et al., 2014, 2016b). This could be because some papers pre-date the common use of the term living shoreline or it could reflect the fact that different terminology is used to appeal to different audiences (e.g., the term living shoreline is often used by non-governmental organizations, whereas the term marsh sill is commonly used by permitting agencies in the United States). Regardless, lack of a shared definition may hinder efforts to incorporate living shorelines into large-scale coastal initiatives and policies (such as those described by Sutton-Grier et al., 2015). A secondary challenge associated with terminology is that living shorelines come in a variety of different forms, each of which may be associated with different terminology. For example, studies in our database used four different habitat types, alone and in combination, and $90 \%$ of papers included sites that also had structural components, ranging from shell and natural fibers to eco-concrete and rock. Standardized terminology is essential to future performance and dissemination of living shorelines research and therefore, implementation. Though a shared definition would not be a panacea, providing a unifying description of living shorelines to local and national policy makers could promote further rulemaking regarding living shorelines, and allow inter-jurisdictional cooperation and sharing of lessons learned. Moreover, an assessment of the relative performance of different structural materials in different environmental contexts is needed to improve best practices.

One of the biggest challenges for translating basic science to practice and policy is that research is currently buried in a growing number of interdisciplinary journals, many of which are locked behind pay walls where practitioners and coastal managers cannot access them (Fuller et al., 2014). The studies in our database were published in 26 unique journals, spanning many sub-disciplines within the environmental sciences. Nearly one third of the papers were open access, compared to the $9 \%$ rate of open access articles that has been noted in other restoration syntheses (Zhang et al., 2018). This may reflect the general growth of open access publishing or may alternatively reflect the highly applied nature of living shorelines research and a push within the community to make research accessible to restoration practitioners and managers that can use the data. Future support for open access publishing should be permissible from granting agencies, universities, and organizations to encourage the transference of knowledge between sectors. 


\section{Recommendations for Future Research}

Our review highlights some important areas of concentrated research as well as gaps in the peer-reviewed literature surrounding living shorelines. Going forward, more studies might be included in a synthesis if the search was expanded beyond peer-reviewed and English-language literature. In regards to research foci, a large proportion of the papers in this review measured processes related to the coastal protective services of living shorelines. Accordingly, it may be possible going forward to conduct a targeted synthesis or meta-analysis to determine whether or not living shorelines can provide superior coastal protection. In terms of research gaps, we suggest that the study of living shorelines could benefit from directed research in the following areas:

- The socio-economic dimensions of living shorelines, particularly relating to their social acceptability among homeowners and municipalities, as well as their installation and maintenance costs over both short and long time scales.

- Long-term performance of living shorelines, which could be achieved by revisiting older sites that have been sampled in previous studies and publishing longer-term data sets to understand how living shoreline functionality changes over time, and how it may change with accelerated sea level rise.

- Direct comparisons between living shorelines and traditional hard infrastructure, to better understand the tradeoffs between different coastal protection strategies.

- The impacts of different living shoreline designs and materials on the delivery of ecosystem services to maximize the functionality of living shorelines in different environmental contexts.

\section{REFERENCES}

Balouskus, R. G., and Targett, T. E. (2012). Egg deposition by atlantic silverside, menidia menidia: substrate utilization and comparison of natural and altered shoreline type. Estuaries Coasts 35, 1100-1109. doi: 10.1007/s12237-012-9495-x

Balouskus, R. G., and Targett, T. E. (2016). Fish and blue crab density along a riprap-sill-hardened shoreline: comparisons with spartina marsh and riprap. Trans. Am. Fish. Soc. 145, 766-773. doi: 10.1080/00028487.2016.1172508

Barbier, E. B., Hacker, S. D., Kennedy, C., Koch, E. W., Stier, A. C., and Silliman, B. R. (2011). The value of estuarine and coastal ecosystem services. Ecol. Monogr. 81, 169-193. doi: 10.1890/10-1510.1

Bayraktarov, E., Saunders, M. I., Abdullah, S., Mills, M., Beher, J., Possingham, H. P., et al. (2016). The cost and feasibility of marine coastal restoration. Ecol. Appl. 26, 1055-1074. doi: 10.1890/15-1077

Bayraktarov, E., Stewart-Sinclair, P. J., Brisbane, S., Boström-Einarsson, L., Saunders, M. I., Lovelock, C. E., et al. (2019). Motivations, success, and cost of coral reef restoration. Restor. Ecol. 27, 981-991. doi: 10.1111/rec.12977

Beck, M. W., Brumbaugh, R. D., Airoldi, L., Carranza, A., Coen, L. D., Crawford, C., et al. (2011). Oyster reefs at risk and recommendations for conservation, restoration, and management. Bioscience 61, 107-116. doi: 10.1525/bio.2011.61.2.5

Benner, C. S., Knutson, P. L., Brochu, R. A., and Hurme, A. K. (1982). Vegetative erosion control in an oligohaline environment Currituck Sound, North Carolina. Wetlands 2, 105-117. doi: 10.1007/BF03160549

Bertness, M., Silliman, B. R., and Jefferies, R. (2004). Salt marshes under siege: agricultural practices, land development and overharvesting of the seas explain

\section{DATA AVAILABILITY STATEMENT}

All datasets generated for this study are included in the article/Supplementary Material.

\section{AUTHOR CONTRIBUTIONS}

CS, MR, and BS conceived of the project. CS, MR, EM, VP, JR, and EW extracted the data. CS, JR, EM, VP, and RG assisted with figure creation. CS wrote the manuscript with help from JR, EW, and EM and critical input from all authors.

\section{FUNDING}

This project was funded by a grant to BS from the Lenfest Ocean Foundation and a grant to RG from the National Science Foundation [Award Number (FAIN): 1901746, Funding Opportunity: PD 19-1638 Humans, Disasters, and the Built Environment].

\section{ACKNOWLEDGMENTS}

This research was partly conducted during a Marine Ecology class at the Duke University Marine Lab and we would like to thank the students that assisted with data extraction.

\section{SUPPLEMENTARY MATERIAL}

The Supplementary Material for this article can be found online at: https://www.frontiersin.org/articles/10.3389/fmars. 2020.00434/full\#supplementary-material

Supplementary Table 1 | Database of living shorelines papers and extracted data used to generate figures and tables for the manuscript.

complex ecological cascades that threaten our shorelines. Am. Sci. 92, 54-61. doi: $10.1511 / 2004.1 .54$

Bilkovic, D., and Roggero, M. (2008). Effects of coastal development on nearshore estuarine nekton communities. Mar. Ecol. Prog. Ser. 358, 27-39. doi: 10.3354/meps07279

Bilkovic, D. M., Mitchell, M., Mason, P., and Duhring, K. (2016). The role of living shorelines as estuarine habitat conservation strategies. Coast. Manag. 44, 161-174. doi: 10.1080/08920753.2016.1160201

Bilkovic, D. M., and Mitchell, M. M. (2013). Ecological tradeoffs of stabilized salt marshes as a shoreline protection strategy: effects of artificial structures on macrobenthic assemblages. Ecol. Eng. 61, 469-481. doi: 10.1016/j.ecoleng.2013.10.011

Bilkovic, D. M., Mitchell, M. M., Peyre, M. K. L., and Toft, J. D. (2017). "Living shorelines the science and management of nature-based coastal protection," in A Primer to Living Shorelines, eds D. M. Bilkovic, M. M. Mitchell, M. K. La Peyre, and J. D. Toft (Boca Raton, FL: CRC Press), 3-10

Broome, S. W., Seneca, E. D., and Woodhouse, W. W. (1986). Long-term growth and development of transplants of the salt-marsh grass Spartina alterniflora. Estuaries 9, 63-74. doi: 10.2307/1352194

Casas, S. M., La Peyre, J., and La Peyre, M. K. (2015). Restoration of oyster reefs in an estuarine lake: population dynamics and shell accretion. Mar. Ecol. Prog. Ser. 524, 171-184. doi: 10.3354/meps11198

Cheong, S.-M., Silliman, B., Wong, P. P., Van Wesenbeeck, B., Kim, C.-K., and Guannel, G. (2013). Coastal adaptation with ecological engineering. Nat. Clim. Chang. 3:787. doi: 10.1038/nclimate1854 
Chowdhury, M. S. N., Walles, B., Sharifuzzaman, S., Shahadat Hossain, M., Ysebaert, T., and Smaal, A. C. (2019). Oyster breakwater reefs promote adjacent mudflat stability and salt marsh growth in a monsoon dominated subtropical coast. Sci. Rep. 9, 1-12. doi: 10.1038/s41598-019-44925-6

Coleman, F. C., and Williams, S. L. (2002). Overexploiting marine ecosystem engineers: potential consequences for biodiversity. Trends Ecol. Evol. 17, 40-44. doi: 10.1016/S0169-5347(01)02330-8

Currin, C. A., Delano, P. C., Lexia, A., Valdes-Weaver, M., Currin, C. A., Delano, P. C., et al. (2008). Utilization of a citizen monitoring protocol to assess the structure and function of natural and stabilized fringing salt marshes in North Carolina. Wetl. Ecol. Manag. 16, 97-118. doi: 10.1007/s11273-0079059-1

Davenport, T. M., Seitz, R. D., Knick, K. E., and Jackson, N. (2018). Living shorelines support nearshore benthic communities in upper and lower chesapeake bay. Estuar. Coasts 41, 197-206. doi: 10.1007/s12237-0170361-8

Davis, J. L., Currin, C. A., O’Brien, C., Raffenburg, C., Davis, A., Currin, C. A., et al. (2015). Living shorelines: coastal resilience with a blue carbon benefit. PLoS ONE 10:e0142595. doi: 10.1371/journal.pone.0142595

De Roo, S., and Troch, P. (2013). Field monitoring of ship wave action on environmentally friendly bank protection in a confined waterway. J. Waterw. Port Coastal Ocean Eng. 139, 527-534. doi: 10.1061/(ASCE)WW.1943-5460.0000202

De Roo, S., and Troch, P. (2015). Evaluation of the effectiveness of a living shoreline in a confined, non-tidal waterway subject to heavy shipping traffic. River Res. Appl. 31, 1028-1039. doi: 10.1002/rra.2790

Donnelly, M., Shaffer, M., Connor, S., Sacks, P., and Walters, L. (2017). Using mangroves to stabilize coastal historic sites: deployment success versus natural recruitment. Hydrobiologia 803, 389-401. doi: 10.1007/s10750-017$3155-\mathrm{x}$

Dugan, J. E., Emery, K. A., Alber, M., Alexander, C. R., Byers, J. E., Gehman, A. M., et al. (2018). Generalizing ecological effects of shoreline armoring across soft sediment environments. Estuar. Coasts 41, S180-S196. doi: $10.1007 / \mathrm{s} 12237-017-0254-\mathrm{x}$

Eden, S. E., and Tunstall, S. (2006). Ecological versus social restoration? How urban river restoration challenges but also fails to challenge the science-policy nexus in the United Kingdom. Environ. Plan. C Gov. Policy 24, 661-680. doi: $10.1068 / \mathrm{c} 0608 \mathrm{j}$

Fuller, R. A., Lee, J. R., and Watson, J. E. M. (2014). Achieving open access to conservation science. Conserv. Biol. 28, 1550-1557. doi: 10.1111/cobi. 12346

Gittman, R. K., Peterson, C. H., Currin, C. A., Fodrie, F. J., Piehler, M. F., Bruno, J. F., et al. (2016b). Living shorelines can enhance the nursery role of threatened estuarine habitats. Ecol. Appl. 26, 249-263. doi: 10.1890/14-0716

Gittman, R. K., Popowich, A. M., Bruno, J. F., and Peterson, C. H. (2014). Marshes with and without sills protect estuarine shorelines from erosion better than bulkheads during a Category 1 hurricane. Ocean Coast. Manag. 102, 94-102. doi: 10.1016/j.ocecoaman.2014.09.016

Gittman, R. K., and Scyphers, S. B. (2017). The cost of coastal protection: a comparison of shore stabilization approaches. Shore Beach 85, 19-24.

Gittman, R. K., Scyphers, S. B., Smith, C. S., Neylan, I. P., and Grabowski, J. H. (2016a). Ecological consequences of shoreline hardening: a meta-analysis. Bioscience 66, 763-773. doi: 10.1093/biosci/biw091

He, Q., and Silliman, B. R. (2019). Climate change, human impacts, and coastal ecosystems in the anthropocene. Curr. Biol. 29, R1021-R1035. doi: 10.1016/j.cub.2019.08.042

Herbert, D., Astrom, E., Bersoza, A. C., Batzer, A., McGovern, P., Angelini, C., et al. (2018). Mitigating erosional effects induced by boat wakes with living shorelines. Sustainability 10. doi: 10.3390/su10020436

Hinkel, J., Lincke, D., Vafeidis, A. T., Perrette, M., Nicholls, R. J., Tol, R. S. J., et al. (2014). Coastal flood damage and adaptation costs under 21st century sea-level rise. Proc. Natl. Acad. Sci.U. S. A. 111, 3292-3297. doi: 10.1073/pnas.1222469111

Hobbs, R. J., and Norton, D. A. (1996). Towards a conceptual framework for restoration ecology. Restor. Ecol. 4, 93-110. doi: 10.1111/j.1526-100X.1996.tb00112.x
Hoegh-Guldberg, O., and Bruno, J. F. (2010). The impact of climate change on the world's marine ecosystems. Science 328, 1523-1528. doi: 10.1126/science. 1189930

Humphries, A. T., and La Peyre, M. K. (2015). Oyster reef restoration supports increased nekton biomass and potential commercial fishery value. PeerJ. 3. doi: $10.7717 /$ peerj.1111

Josephs, L. I., and Humphries, A. T. (2018). Identifying social factors that undermine support for nature-based coastal management. J. Environ. Manage. 212, 32-38. doi: 10.1016/j.jenvman.2018.01.085

Kamali, B., and Hashim, R. (2011). Mangrove restoration without planting. Ecol. Eng. 37, 387-391. doi: 10.1016/j.ecoleng.2010.11.025

Kibler, K. M., Kitsikoudis, V., Donnelly, M., Spiering, D. W., and Walters, L. (2019). Flow-vegetation interaction in a living shoreline restoration and potential effect to mangrove recruitment. Sustainability 11. doi: 10.3390/su11113215

Knutson, P. L., Ford, J. C., Inskeep, M. R., and Oyler, J. (1981). National survey of planted salt marshes (vegetative stabilization and wave stress). Wetlands. 1, 129-157. doi: 10.1007/BF03160460

Kochnower, D., Reddy, S. M., and Flick, R. E. (2015). Factors influencing local decisions to use habitats to protect coastal communities from hazards. Ocean Coast. Manag. 116, 277-290. doi: 10.1016/j.ocecoaman.2015. 07.021

La Peyre, M. K., Humphries, A. T., Casas, S. M., and La Peyre, J. F. (2014). Temporal variation in development of ecosystem services from oyster reef restoration. Ecol. Eng. 63, 34-44. doi: 10.1016/j.ecoleng.2013. 12.001

La Peyre, M. K., Serra, K., Joyner, T. A., and Humphries, A. (2015). Assessing shoreline exposure and oyster habitat suitability maximizes potential success for sustainable shoreline protection using restored oyster reefs. PeerJ. 2015, 1-17. doi: $10.7717 /$ peerj. 1317

Lawless, A. S., and Seitz, R. D. (2014). Effects of shoreline stabilization and environmental variables on benthic infaunal communities in the Lynnhaven River System of Chesapeake Bay. J. Exp. Mar. Bio. Ecol. 457, 41-50. doi: 10.1016/j.jembe.2014.03.010

Lee, S. Y., Dunn, R. J. K., Young, R. A., Connolly, R. M., Dale, P. E. R., Dehayr, R., et al. (2006). Impact of urbanization on coastal wetland structure and function. Austral. Ecol. 31, 149-163. doi: 10.1111/j.1442-9993.2006. 01581.x

Lotze, H. K., Lenihan, H. S., Bourque, B. J., Bradbury, R. H., Cooke, R. G., Kay, M. C., et al. (2006). Depletion degradation, and recovery potential of estuaries and coastal seas. Science (80-.) 312, 1806-1809. doi: 10.1126/science.1128035

Manis, J. E., Garvis, S. K., Jachec, S. M., and Walters, L. J. (2015). Wave attenuation experiments over living shorelines over time: a wave tank study to assess recreational boating pressures. J. Coast. Conserv. 19, 1-11. doi: 10.1007/s11852-014-0349-5

Martin, D. M. (2017). Ecological restoration should be redefined for the twentyfirst century. Restor. Ecol. 25, 668-673. doi: 10.1111/rec.12554

McGranahan, G., Balk, D., and Anderson, B. (2007). The rising tide: assessing the risks of climate change and human settlements in low elevation coastal zones. Environ. Urban. 19, 17-37. doi: 10.1177/095624780 7076960

Mcleod, E., Chmura, G. L., Bouillon, S., Salm, R., Björk, M., Duarte, C. M., et al. (2011). A blueprint for blue carbon: toward an improved understanding of the role of vegetated coastal habitats in sequestering $\mathrm{CO}_{2}$. Front. Ecol. Environ. 9, 552-560. doi: 10.1890/110004

Meyer, D. L., and Townsend, E. C. (2000). Faunal utilization of created intertidal eastern oyster (Crassostrea virginica) reefs in the southeastern United States. Estuaries 23, 34-45. doi: 10.2307/1353223

Meyer, D. L., Townsend, E. C., and Thayer, G. W. (1997). Stabilization and erosion control value of oyster cultch for intertidal marsh. Restor. Ecol. 5, 93-99. doi: 10.1046/j.1526-100X.1997.09710.x

Milbrandt, E. C., Thompson, M., Coen, L. D., Grizzle, R. E., and Ward, K. (2015). A multiple habitat restoration strategy in a semi-enclosed Florida embayment, combining hydrologic restoration, mangrove propagule plantings and oyster substrate additions. Ecol. Eng. 83, 394-404. doi: 10.1016/j.ecoleng.2015. 06.043 
Mitchell, M., and Bilkovic, D. (2019). Embracing dynamic design for climate-resilient living shorelines. J. Appl. Ecol. 56, 1099-1105. doi: $10.1111 / 1365-2664.13371$

Mitsch, W. J. (2012). What is ecological engineering? Ecol. Eng. 45, 5-12. doi: 10.1016/j.ecoleng.2012.04.013

Moher, D., Liberati, A., Tetzlaff, J., Altman, D., and Group, T. P. (2009). Preferred reporting items for systematic reviews and meta-analyses: the PRISMA Statement. PLoS Med 6:e1000097. doi: 10.1371/journal.pmed.10 00097

Moody, R. M., Cebrian, J., Kerner, S. M., Heck, K. L. Jr., Powers, S. P., et al. (2013). Effects of shoreline erosion on salt-marsh floral zonation. Mar. Ecol. Prog. Ser. 488, 145-155. doi: 10.3354/meps10404

Morris, R. L., Bilkovic, D. M., Boswell, M. K., Bushek, D., Cebrian, J., Goff, J., et al. (2019). The application of oyster reefs in shoreline protection: are we over-engineering for an ecosystem engineer? J. Appl. Ecol. 56, 1703-1711. doi: 10.1111/1365-2664.13390

Morris, R. L., Konlechner, T. M., Ghisalberti, M., and Swearer, S. E. E. (2018). From grey to green: efficacy of eco-engineering solutions for nature-based coastal defence. Glob. Chang. Biol. 24, 1827-1842. doi: 10.1111/gcb.14063

Motamedi, S., Hashim, R., Zakaria, R., Song, K., and Sofawi, B. (2014). Longterm assessment of an innovative mangrove rehabilitation project: case study on Carey Island, Malaysia. Sci. World J. 2014. doi: 10.1155/2014/953830

Naohiro, M., Putth, S., and Keiyo, M. (2012). Mangrove rehabilitation on highly eroded coastal shorelines at Samut Sakhon, Thailand. Int. J. Ecol. 2012. doi: $10.1155 / 2012 / 171876$

Narayan, S., Beck, M. W., Reguero, B. G., Losada, I. J., Van Wesenbeeck, B., Pontee, N., et al. (2016). The effectiveness, costs and coastal protection benefits of natural and nature-based defences. PLOS ONE 11:e0154735. doi: 10.1371/journal.pone. 0154735

National Research Council (2007). Mitigating Shore Erosion Along Sheltered Coasts. Washington, DC: The National Academies Press. doi: 10.17226/11764

Nesshöver, C., Assmuth, T., Irvine, K. N., Rusch, G. M., Waylen, K. A., Delbaere, B., et al. (2017). The science, policy and practice of nature-based solutions: an interdisciplinary perspective. Sci. Total Environ. 579, 1215-1227. doi: 10.1016/j.scitotenv.2016.11.106

NOAA (2015). Guidance for Considering the Use of Living Shorelines. Available online at: https://www.habitatblueprint.noaa.gov/wp-content/uploads/2018/ 01/NOAA-Guidance-for-Considering-the-Use-of-Living-Shorelines_2015. pdf (accessed September 7, 2019).

NRC (1992). Restoration of Aquatic Ecosystems: Science, Technology, and Public Policy. Available online at: https://books.google.com/ books?hl=en\&lr=\&id=Hz1ZHDFPOx0C\&oi=fnd\&pg=PR22\&ots= 15HRbpUM4j\&sig=BDilB7WqNKCNmZQ1L0IQtvek0JY\#v=onepage\&q= thereturnofanecosystem $\& \mathbb{f} \$=\$$ false (accessed September 7, 2019).

O'Connor, M. I., Violin, C. R., Anton, A., Ladwig, L. M., and Piehler, M. F. (2011). Salt marsh stabilization affects algal primary producers at the marsh edge. Wetl. Ecol. Manag. 19, 131-140. doi: 10.1007/s11273-010-9206-y

Onorevole, K. M., Thompson, S. P., and Piehler, M. F. (2018). Living shorelines enhance nitrogen removal capacity over time. Ecol. Eng. 120, 238-248. doi: 10.1016/j.ecoleng.2018.05.017

Palinkas, C. M., Sanford, L. P., and Koch, E. W. (2018). Influence of shoreline stabilization structures on the nearshore sedimentary environment in mesohaline chesapeake bay. Estuar. Coasts 41, 952-965. doi: 10.1007/s12237-017-0339-6

Palmer, M. A., Filoso, S., and Fanelli, R. M. (2014). From ecosystems to ecosystem services: stream restoration as ecological engineering. Ecol. Eng. 65, 62-70. doi: 10.1016/j.ecoleng.2013.07.059

Patrick, C. J., Weller, D. E., and Ryder, M. (2016). The relationship between shoreline armoring and adjacent submerged aquatic vegetation in chesapeake bay and nearby atlantic coastal bays. Estuar. Coasts 39, 158-170. doi: 10.1007/s12237-015-9970-2

Peters, J. R., Yeager, L. A., and Layman, C. A. (2015). Comparison of fish assemblages in restored and natural mangrove habitats along an urban shoreline. Bull. Mar. Sci. 91, 125-139. doi: 10.5343/bms.2014.1063

Piazza, B. P., Banks, P. D., and La Peyre, M. K. (2005). The potential for created oyster shell reefs as a sustainable shoreline protection strategy in Louisiana. Restor. Ecol. 13, 499-506. doi: 10.1111/j.1526-100X.2005.00062.x
Polk, M. A., and Eulie, D. O. (2018). Effectiveness of living shorelines as an erosion control method in North Carolina. Estuar. Coasts 41, 2212-2222. doi: 10.1007/s12237-018-0439-y

Pullin, A. S., and Knight, T. M. (2001). Effectiveness in conservation practice: pointers from medicine and public health. Conserv. biol. 15, 50-54.

Pullin, A. S., Knight, T. M., Stone, D. A., and Charman, K. (2004). Do conservation managers use scientific evidence to support their decision-making? Biol. Conserv. 119, 245-252. doi: 10.1016/j.biocon.2003.11.007

Ruiz-Jaen, M. C., and Aide, T. M. (2005). Restoration success: how is it being measured? Restor. Ecol. 13, 569-577. doi: 10.1111/j.1526-100X.2005. 00072.x

Scyphers, S. B., Picou, J. S., and Powers, S. P. (2015a). Participatory conservation of coastal habitats: the importance of understanding homeowner decision making to mitigate cascading shoreline degradation. Conserv. Lett. 8, 41-49. doi: $10.1111 /$ conl.12114

Scyphers, S. B., Powers, S. P., and Heck, K. L. (2015b). Ecological value of submerged breakwaters for habitat enhancement on a residential scale. Environ. Manage. 55, 383-391. doi: 10.1007/s00267-014-0394-8

Scyphers, S. B., Powers, S. P., Heck, K. L., Byron, D., and Coen, L. (2011). Oyster reefs as natural breakwaters mitigate shoreline loss and facilitate fisheries. PLoS ONE 6:e22396. doi: 10.1371/journal.pone.0022396

Seitz, R. D., Lipcius, R. N., Olmstead, N. H., Seebo, M. S., and Lambert, D. M. (2006). Influence of shallow-water habitats and shoreline development on abundance, biomass, and diversity of benthic prey and predators in Chesapeake Bay. Mar. Ecol. Prog. Ser. 326, 11-27. doi: 10.3354/meps 326011

Sharma, S., Goff, J., Cebrian, J., and Ferraro, C. (2016). A hybrid shoreline stabilization technique: impact of modified intertidal reefs on marsh expansion and nekton habitat in the northern Gulf of Mexico. Ecol. Eng. 90, 352-360. doi: 10.1016/j.ecoleng.2016.02.003

Silliman, B. R., He, Q., Angelini, C., Smith, C. S., Kirwan, M. L., Daleo, P., et al. (2019). Field experiments and meta-analysis reveal wetland vegetation as a crucial element in the coastal protection paradigm. Curr. Biol. 29:1800. doi: 10.1016/j.cub.2019.05.017

Smith, C. S., Gittman, R. K., Neylan, I. P., Scyphers, S. B., Morton, J. P., Joel Fodrie, F., et al. (2017). Hurricane damage along natural and hardened estuarine shorelines: using homeowner experiences to promote nature-based coastal protection. Mar. Policy 81, 350-358. doi: 10.1016/j.marpol.2017.04.013

Smith, C. S., Puckett, B., Gittman, R. K., and Peterson, C. H. (2018). Living shorelines enhanced the resilience of saltmarshes to Hurricane Matthew (2016). Ecol. Appl. 28, 871-877. doi: 10.1002/eap.1722

Strain, E. M. A., Alexander, K. A., Kienker, S., Morris, R., Jarvis, R., Coleman, R., et al. (2019). Urban blue: a global analysis of the factors shaping people's perceptions of the marine environment and ecological engineering in harbours. Sci. Total Environ. 658, 1293-1305. doi: 10.1016/j.scitotenv.2018.12.285

Stricklin, A. G., Peterson, M. S., Lopez, J. D., May, C. A., Mohrman, C. F., and Woodrey, M. S. (2010). Do small, patchy, constructed intertidal oyster reefs reduce salt marsh erosion as well as natural reefs? Gulf Caribb. Res. 22, 21-27. doi: $10.18785 / \mathrm{gcr} .2201 .03$

Sutherland, W. J., Pullin, A. S., Dolman, P. M., and Knight, T. M. (2004). The need for evidence-based conservation. Trends Ecol. Evol. 19, 305-308. doi: 10.1016/j.tree.2004.03.018

Sutton-Grier, A. E., Gittman, R. K., Arkema, K. K., Bennett, R. O., Benoit, J., Blitch, S., et al. (2018). Investing in natural and nature-based infrastructure: building better along our coasts. Sustainability 10:523. doi: 10.3390/su10020523

Sutton-Grier, A. E., Wowk, K., and Bamford, H. (2015). Future of our coasts: the potential for natural and hybrid infrastructure to enhance the resilience of our coastal communities, economies and ecosystems. Environ. Sci. Policy 51, 137-148. doi: 10.1016/j.envsci.2015.04.006

Temmerman, S., Meire, P., Bouma, T. J., Herman, P. M. J., Ysebaert, T., and De Vriend, H. J. (2013). Ecosystem-based coastal defence in the face of global change. Nature 504, 79-83. doi: 10.1038/nature12859

Titus, J. G. (1998). Rising seas, coastal erosion, and the takings clause: how to save wetlands and beaches without hurting property owners. Maryl. Law Rev. 57, 1279-1399.

United States Army Corps of Engineers (2016). Washington, DC: Nationwide Permit 54: Living Shorelines. 
Valiela, I., Bowen, J. L., and York, J. K. (2001). Mangrove forests: one of the world's threatened major tropical environments. Bioscience 51, 807-815. doi: 10.1641/ 0006-3568(2001)051[0807:MFOOTW]2.0.CO;2

Van Cuong, C., Brown, S., To, H. H., and Hockings, M. (2015). Using Melaleuca fences as soft coastal engineering for mangrove restoration in Kien Giang, Vietnam. Ecol. Eng. 81, 256-265. doi: 10.1016/j.ecoleng.2015.04.031

Walles, B., Troost, K., van den Ende, D., Nieuwhof, S., Smaal, A. C., and Ysebaert, T. (2016). From artificial structures to self-sustaining oyster reefs. J. Sea Res. 108, 1-9. doi: 10.1016/j.seares.2015.11.007

Wiberg, P. L., Taube, S. R., Ferguson, A. E., Kremer, M. R., and Reidenbach, M. A. (2019). Wave attenuation by oyster reefs in shallow coastal bays. Estuar. Coasts 42, 331-347. doi: 10.1007/s12237-018-0463-y

Wortley, L., Hero, J., and Howes, M. (2013). Evaluating ecological restoration success: a review of the literature. Restor. Ecol. 21, 537-543. doi: $10.1111 /$ rec. 12028
Zhang, Y. S., Cioffi, W. R., Cope, R., Daleo, P., Heywood, E., Hoyt, C., et al. (2018). A global synthesis reveals gaps in coastal habitat restoration research. Sustainability 10. doi: 10.3390/su10041040

Conflict of Interest: The authors declare that the research was conducted in the absence of any commercial or financial relationships that could be construed as a potential conflict of interest.

Copyright (C) 2020 Smith, Rudd, Gittman, Melvin, Patterson, Renzi, Wellman and Silliman. This is an open-access article distributed under the terms of the Creative Commons Attribution License (CC BY). The use, distribution or reproduction in other forums is permitted, provided the original author(s) and the copyright owner(s) are credited and that the original publication in this journal is cited, in accordance with accepted academic practice. No use, distribution or reproduction is permitted which does not comply with these terms. 